\title{
PASPALUM: Jurnal Ilmiah Pertanian
}

Vol. 8 No. 2 Bulan September Tahun 2020

DOI: http://dx.doi.org/10.35138/paspalum.v8i2.199

\section{Keragaan Produktivitas Padi Sawah Jawa Barat Dan Faktor Yang Mempengaruhinya}

\author{
Juri Juswadi, Pandu Sumarna, Neneng Sri Mulyati \\ Fakultas Pertanian Universitas Wiralodra Indramayu \\ jurijuswadi@unwir.ac.id
}

(Received: 29-Juli-2020; Published: 30-Sept-2020)

\begin{abstract}
This study aims to describe the performance of West Java wet land paddy productivity in the period 1997-2017, and identify the factors that influence it. Descriptive research results show that during the period 1997-2017, the average productivity of wet land paddy in West Java that observed from 16 districts experienced an increase from $53.22 \mathrm{Kw} / \mathrm{ha}$ in 1997 to $60.79 \mathrm{Kw} / \mathrm{ha}$ ton in 2017 , with average productivity per year is $55.92 \mathrm{Kw} / \mathrm{ha}$. Wet land paddy productivity has increased by $7.57 \mathrm{Kw} / \mathrm{ha}$ or an increase in an average of $0.83 \%$ per year. Increased productivity has fluctuated with a negative increase occurred in 1998, 2001, 2004, 2010, 2012, 2014, 2014, 2015 and 2017. There is still a gap between factual wet land paddy productivity with potential productivity of some superior varieties of wet land paddy. The results of statistical analysis of factors that affect wet land paddy productivity in West Java show that variable altitude and rainfall have a significant effect on wet land paddy productivity, while the irrigation area and cropping index (IP) have no significant effect.
\end{abstract}

Keywords: wet land paddy, wet land paddy productivity, productivity gap, Cropping Index (CI)

\begin{abstract}
ABSTRAK
Penelitian ini bertujuan untuk mendeskripsi keragaan produktivitas padi sawah Jawa Barat periode 1997-2017, dan mengidentifikasi faktor-faktor yang mempengaruhinya. Hasil penelitian deksriptif menunjukkan bahwa sepanjang periode 1997-2017, produktivitas padi sawah rata-rata di Jawa Barat yang diamati dari 16 kabupaten mengalami peningkatan dari 53,22 Kw/ha pada tahun 1997 menjadi 60,79 Kw/ha ton pada tahun 2017, dengan rata-rata produktivitas per tahun sebesar 55,92 Kw/ha. Produktivitas padi sawah telah meningkat 7,57 Kw/ha atau peningkatan rata-rata $0,83 \%$ per tahun. Peningkatan produktivitas terjadi fluktuatif dengan peningkatan negatif terjadi pada tahun 1998, 2001, 2004, 2010, 2012, 2014, 2015, dan 2017. Masih terdapat kesenjangan (gap) antara produktivitas padi sawah faktual dengan produktivitas potensial beberapa varietas unggul padi sawah. Hasil analisis statistik faktor yang mempengaruhi produktivitas padi sawah di Jawa Barat menunjukkan variabel ketinggian tempat dan curah hujan berpengaruh nyata terhadap produktivitas padi sawah, sedangkan variabel luas irigasi dan indeks pertanaman (IP) tidak berpengaruh nyata.
\end{abstract}

Kata kunci: padi sawah, produktivitas padi sawah, kesenjangan produktivitas, indeks pertanaman (IP) 


\section{PENDAHULUAN}

Komoditas padi berperan startegis sebagai makanan pokok bagi lebih dari 250 juta penduduk Indonesia. Peningkatan produktivitas padi terus menerus diperlukan untuk mengimbangi meningkatnya jumlah penduduk. Produktivitas padi sawah merupakan rasio antara jumlah produksi padi sebagai otuput terhadap luas panen sebagai input. Trend penurunan luas lahan sawah hampir merata di semua wilayah Indonesia, yang dapat berimbas pada penurunan produksi padi. Upaya peningkatan produktivitas merupakan solusi untuk meningkatkan produksi padi. Jawa Barat sebagai salah satu wilayah produsen padi nasional tidak lepas dari fenomena tersebut. Terlebih lagi sebagian wilayahnya seperti kabupaten/kota Bogor, Depok, Bekasi, dan Kerawang terletak di dekat ibukota negara sehingga berdampak pada alih fungsi lahan yang intensif.

Semua kabupaten di Jawa Barat menghasilkan padi sawah dengan produktivitas yang berbeda-beda. Berbagai faktor dapat mempengaruhinya seperti keterampilan tenaga kerja (petani), asupan sarana produksi pertanian, dan teknologi pertanian yang digunakan. Perbedaan tersebut juga disebabkan oleh keadaan wilayah, seperti seperti dataran rendah di wilayah pantai utara (pantura) dan dataran tinggi di bagian tengah dan selatan. Jenis tanah aluvial dan grumosol yangdominan di wilayah pantura serta latosol, podsolik, regosol dan jenis tanah lainnya di wilayah tengah dan selatan. Demikiaan pula terdapat perbedaan iklim yang menyertai wilayah tersebut, seperti curah hujan yang lebih rendah di wilayah pantura.

Provinsi Jawa Barat merupakan daratan yang dibedakan atas wilayah pegunungan curam di selatan dengan ketinggian lebih dari $1.500 \mathrm{~m} \mathrm{dpl}$, wilayah lereng bukit yang landai di tengah dengan ketinggian 100-1.500 m dpl, wilayah dataran luas di utara dengan ketinggian 0-10 $\mathrm{m}$ dpl, dan wilayah aliran sungai. Jawa Barat terletak pada posisi antara $5^{\circ} 50^{\prime}-7^{\circ} 50^{\prime}$ Lintang Selatan dan $104^{\circ} 48^{\prime}$ - $108^{\circ} 48^{\prime}$ Bujur Timur. Luas wilayah Jawa Barat adalah berupa daratan seluas $35.377,76$ km2. Wilayah Provinsi Jawa Barat bagian utara berbatasan dengan Laut Jawa, bagian selatan berbatasan dengan Samudera Hindia, bagian barat berbatasan dengan Provinsi Banten dan Provinsi DKI Jakarta, dan bagian timur berbatasan dengan Provinsi Jawa Tengah (BPS, 2019).

Provinsi Jawa Barat memiliki kondisi alam dengan struktur geologi yang kompleks dengan wilayah pegunungan berada di bagian tengah dan selatan serta dataran rendah di wilayah utara. Memiliki kawasan hutan dengan fungsi hutan konservasi, hutan lindung dan hutan produksi yangproporsinya mencapai $22,10 \%$ dari luas Jawa Barat; curah hujan berkisar antara 2000-4000 mm/th dengan tingkat intensitas hujan tinggi; memiliki 40 Daerah Aliran Sungai (DAS) dengan debit air permukaan 81 milyar $\mathrm{m}^{3} /$ tahun dan air tanah 150 juta $^{3} /$ th. (BPS, 2020). Pada tahun 2015, memiliki luas lahan sawah beririgasi 736.635 ha, tadah hujan 180.084 ha, dan lebak 661 ha (BPS, 2018).

Budidaya dan usahatani padi sawah di Jawa Barat memiliki sejarah panjang mulai dari pertanian tradisional sebelum tahun enampuluhan, selanjutnya pertanian modern sampai saat ini yang dikenal sebagai revolusi hijau, serta pertanian organik yang menyertainya. Salah satu teknologi pertanian modern tersebut adalah penggunaan varietas unggul. Menurut Nurhati dkk, (2008), di Jawa Barat hingga tahun 2002 varietas IR64 masih mendominasi $42 \%$ areal pertanaman padi sawah, kemudian diikuti oleh varietas Way Apo Buru 19,1\%, Ciherang 12,7\%, Widas 6,9\%, Cilamaya Muncul 2,3\%, Memberamo 2,2\%, dan Cisadane 1,8\%. Pada tahun 2004, varietas Ciherang menggeser dominasi varietas IR64 dan terus berlanjut sampai saat ini. Beberapa varietas unggul yang baru dilepas seperti Cigeulis, Situ Bagendit, dan Mekongga mulai diminati petani dan berkembang di Kabupaten Subang, Indramayu, Purwakarta, Cianjur, dan Tasikmalaya. Produktivitas padi sawah di Jawa Barat sepanjang lima tahun 
terakhir rata-rata 5,31 t/ha dengan produktivitas terendah 5,15 t/ha pada tahun 2001 dan tertinggi 5,50 t/ha pada tahun 2003.

Penelitian terdahulu banyak dilakukan untuk mengetahui faktor-faktor alam yang mempengaruhi produksi dan produktivitas padi. Penelitian Ishaq, Rumiati, dan Permatasari (2017) menemukan bahwa ketinggian rata-rata dari permukaan laut cenderung acak, sehingga variabel tersebut merupakan variabel nonparametrik yang mempengaruhi produksi. Faradiba (2020) menemukan peningkatan produktivitas padi sawah di Jawa Barat terjadi pada tahun 2006, 2009, 2012, 2015 sesuai dengan pola curah hujan yang terjadi setiap tiga tahun. Upadhyay (2012) menyatakan kenaikan suhu berdampak negatif pada produktivitas tanaman padi dan curah hujan memiliki dampak positif pada produktivitas tanaman padi. Sihombing, Arifin, dan Handayati (2019) menyatakan alternatif untuk mengoptimalkan penggunaan lahan kering melalui intensifikasi pengelolaan lahan adalah mengganti intensitas pertanaman (cropping intensity) atau indeks pertanaman (cropping index) dari penanaman padi satu kali hingga dua kali dalam setahun. Ding dkk (2016) menyatakan intensitas pertanaman yang penting dalam menyeimbangkan produksi makanan dan meningkatnya permintaan lahan untuk urbanisasi yang cepat. Ahmad dan Abbas (2003) serta Raghav and Imai (2008) menemukan bahwa luas lahan teririgasi mempengaruhi produktivitas lahan pertanian pertanian. Supriatna (2012) menyatakan salah satu determinan utama peningkatan produksi pangan, khususnya beras adalah ketersediaan lahan sawah iririgasi. Menurut Rejekiningrum \& Kartiwa (2015), pemberian air irigasi dan waktu pemberian sangat penting untuk meningkatkan efisiensi penggunaan air dan memaksimalkan produksi.

Melanjutkan penelitian terdahulu, penelitian ini bertujuan untuk mengatahui keragaan produktivitas padi sawah di Provinsi Jawa Barat, serta mengidentifikasi sejauhmana pengaruh varabel ketinggian tempat, curah hujan, indeks pertanaman, dan luas irigasi terhadap produktivitas padi sawah. Hasil penelitian diharapkan diperoleh rekomendasi bagi peningkatan produktivitas padi sawah melalui identifikasi faktor-faktor yang mempengaruhinya.

\section{METODE}

Penelitian ini merupakan penelitian deskriptif yang bertujuan untuk mengidentifikasi keragaan produktivitas padi sawah dan pertumbuhannya pada 16 kabupaten di Jawa Barat, yaitu: Bogor, Sukabumi, Cianjur, Bandung, Garut, Tasikmalaya, Ciamis, Kuningan, Cirebon, Majalengka, Sumedang, Indramayu, Subang, Purwakarta, Karawang, dan Bekasi, sepanjang periode 1997-2017. Data yang digunakan adalah data sekunder dari Jawa Barat dalam Angka Tahun 1997 sampai dengan tahun 2018. Selanjutnya penelitian eksplanatori bertujuan untuk mengetahui pengaruh faktorfaktor: ketinggian tempat, curah hujan, indeks pertanaman (IP), dan luas irigasi terhadap produktivitas padi sawah. Alat analisis menggunakan model persamaan fungsi produksi Cobb Douglas untuk mengidentifikasi faktor-faktor yang berpengaruh terhadap produktivitas padi sawah. Analisis ini menggunakan data cross section tahun 2013 dari 16 Kabupaten di Jawa Barat yang merupakan data sekunder berasal dari Jawa Barat dalam Angka Tahun 2014.. Pemilihan tahun 2013 didasarkan pada nilai simpangan baku produktivitas padi sawah tertinggi pada tahun tersebut, yaitu 3,90 Kw/ha.

\section{HASIL DAN PEMBAHASAN}

\section{Keragaan Produktivitas Padi Sawah di Jawa Barat}

Produktivitas padi sawah rata-rata tahunan yang diperoleh dari 16 kabupaten di Jawa Barat menunjukkan nilai yang cukup ragam diantara kabupaten yang ditandai oleh nilai simpangan baku berkisar dari 1,45 ku/ha sampai dengan 3,90 $\mathrm{Kw} / \mathrm{ha}$ dan simpangan baku rata-rata $2,43 \mathrm{Kw} / \mathrm{ha}$. Terdapat 
kecenderungan peningkatan simpangan baku mulai tahun 2013 sampai dengan tahun 2017. Keragaman produktivitas padi sawah rata-rata diantara 16 kabupaten tersebut merupakan salah satu indikator sejauhmana tingkat penerapan teknologi budidaya tanaman padi sawah di Jawa Barat dengan wilayah yang memiliki keragaman dalam ketinggian tempat, bentuk wilayah, iklim, dan jenis tanah.

Sepanjang periode 1997-2017, produktivitas padi sawah rata-rata di Jawa Barat yang diamati dari 16 kabupaten meningkat dari rata-rata $53,22 \mathrm{Kw} / \mathrm{ha}$ pada tahun 1997 menjadi rata-rata $60,79 \mathrm{Kw} / \mathrm{ha}$ ton pada tahun 2017, dengan rata-rata produktivitas per tahun sebesar 55,92 Kw/ha. Sepanjang periode tersebut, produktivitas padi sawah telah meningkat $7,57 \mathrm{Kw} / \mathrm{ha}$ atau peningkatan rata-rata $0,83 \%$ per tahun. Dibutuhkan waktu dua dekade untuk meningkatkan nilai produktivitas tersebut. Grafik perkembangan produktivitas padi sawah yang dihasilkan oleh 16 kabupaten di Jawa Barat sepanjang periode 1997-2017 ditunjukkan oleh Gambar 1. Produktivitas padi sawah rata-rata tertinggi yang pernah dicapai terjadi pada tahun 2016, yaitu sebesar $61.39 \mathrm{Kw} / \mathrm{ha}$.

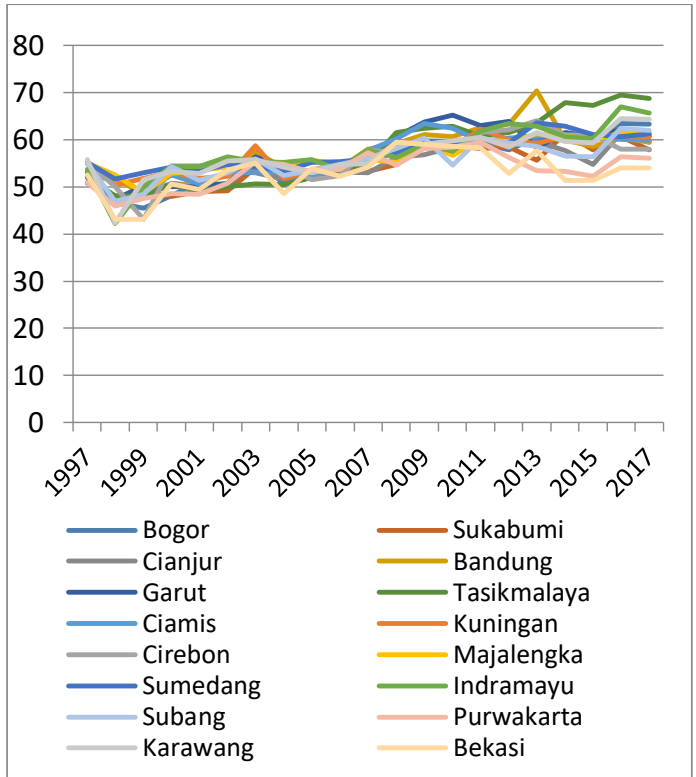

Sumber: Jawa Barat dalam Angka Tahun 1997-2018 (diolah) Gambar 1. Produktivitas Padi Sawah Rata-rata per tahun pada 16 Kabupaten di Jawa Barat 1997-2017 (Kw/ha)
Pengamatam pada masing-masing kabupaten menunjukkan produktivitas padi sawah tertinggi dicapai oleh Kabupaten Tasikmalaya sebesar 70,31 kw/ha pada tahun 2013, sedangkan terendah sebesar 42,16 kw/ha terjadi di Kabupaten Indramayu pada tahun 1998. Produktivitas padi sawah rata-rata tertinggi per kabupaten per tahun sepanjang periode 1997-2017 dijumpai di Kabupaten Indramayu, yaitu sebesar 57,65 Kw/ha dan terendah di Kabupaten Purwakarta sebesar $52,98 \mathrm{Kw} / \mathrm{ha}$. Peningkatan produktivitas padi sawah rata-rata Jawa Barat terjadi fluktuatif, bahkan terjadi peningkatan yang negatif pada tahun 1998, 2001, 2004, 2010, 2012, 2014, 2015, dan 2017, dengan rata-rata peningkatan produktivitas $0,83 \%$ per tahun, seperti ditunjukkan oleh Gambar 2.

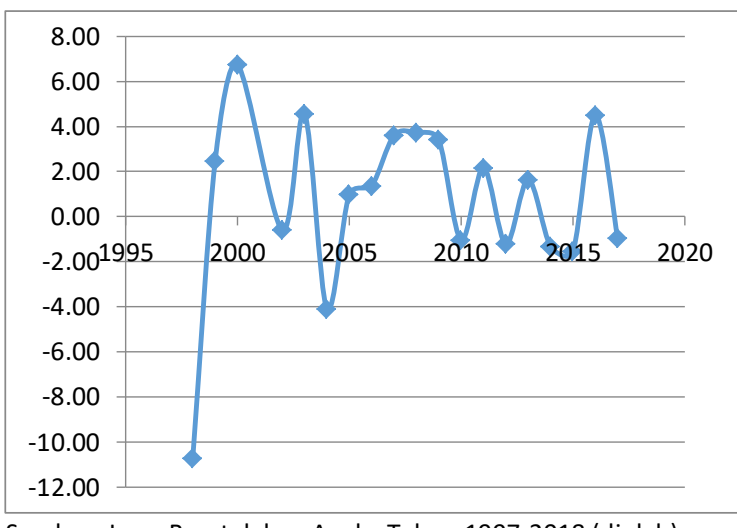

Sumber: Jawa Barat dalam Angka Tahun 1997-2018 (diolah)

Gambar 2. Pertumbuhan Produktivitas Padi

Sawah Rata-rata per tahun pada 16 Kabupaten di Jawa Barat 1998-2017 (\%)

Luas panen padi sawah pada 16 kabupaten di Jawa Barat merupakan input utama bagi produksi padi Jawa Barat. Sepanjang periode 1997-2007 luas panen mengalami fluktuasi, yaitu peningkatan luas pada tahun 2000, 2001, 2004, 2005, 2007, 2009, 2010, 20013, dan 2016, sedangkan pada tahun lainnya mengalami penurunan. Dilihat dari rata-rata per tahun sepanjang periode tersebut, terjadi peningkatan luas panen padi sawah rata-rata sebesar $0,60 \%$ pertahun. Luas panen pada tahun 1997 adalah sebesar 1.697.649 ha menjadi 1765.895 ha pada tahun 2016. Fluktuasi luas panen padi sawah berkontribusi pada produktivitas padi sawah, karena 
peningkatan produktivitas padi sawah dapat disebabkan oleh meningkatnya produksi gabah (output) pada luas panen (input) yang tetap atau sebaliknya pada saat produksi gabah tetap tetapi luas panen menurun. Perkembangan luas panen padi sawah dari 16 kabupaten di Jawa Barat sepanjang periode 1997-2017 dapat dilihat pada Gambar 3. Luas panen tertinggi terjadi pada tahun 2010, yaitu 1.958.031 ha dan terendah pada tahun 2003, yaitu 1.501.397 ha.

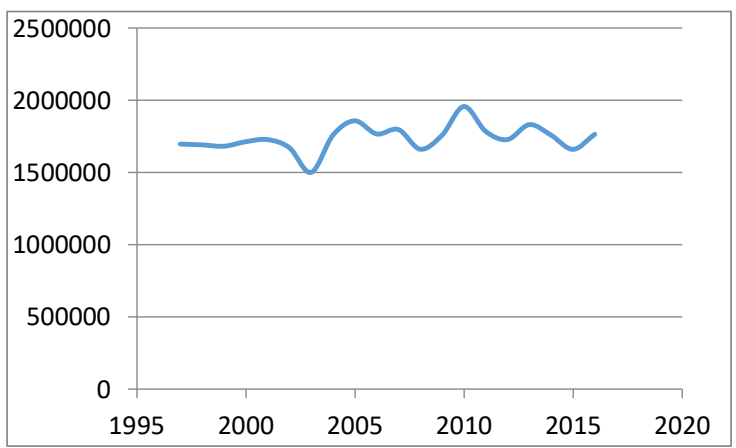

Sumber: Jawa Barat dalam Angka Tahun 1997-2018 (diolah)

Gambar 3. Luas Panen Padi Sawah pada 16

Kabupaten di Jawa Barat 1997-2016 (ha)

Budidaya padi sawah Jawa Barat sepanjang periode 1997-2017 berada pada era revolusi hijau yang mampu meningkatkan produktivitas rata-rata sebesar $0,83 \%$ per tahun. Pertumbuhan produktivitas padi sawah cenderung melandai mulai periode 2012-2017 seperti ditujukkan oleh Gambar 1. Jika dibandingkan dengan potensi hasil varietas unggul yang umum digunakan di Jawa Barat maka masih ada kesenjangan (gap) produktivitas sekitar 2-3 ton/ha dibandingkan rata-rata produktivitas $55,92 \mathrm{Kw} / \mathrm{ha}$. Menurut Lobell, Cassman, dan Field (2009), kesenjangan hasil (yield gap) dihitung dengan cara mengurangi potensi hasil oleh hasil ratarata yang dicapai.

Masih adanya kesenjangan tersebut merupakan indikator perlunya perubahan sistem budidaya tanaman padi sawah dari kondisi produktivitasnya yang sudah melandai ke sistem budidaya lain seperti pertanian berkelanjutan yang memiliki potensi peningkatan produktivitas yang lebih tinggi dengan memeprtahankan kualitas lingkungan yang baik. Pushpa dan Srivastava (2014) menyatakan upaya harus dilakukan untuk memperbarui pengetahuan petani tentang penyebab kesenjangan hasil pada tanaman dan langkah-langkah untuk mempersempit kesenjangan melalui pelatihan, demonstrasi, kunjungan lapangan dan pemantauan oleh lembaga penyuluhan untuk mencapai hasil tinggi.

Pertumbuhan produktivitas padi sawah tersebut masih dapat ditingkatkan jika melihat potensi hasil dari varietas unggul padi yang banyak digunakan seperti ditunjukkan oleh Tabel 1. Potensi hasil yang tinggi pada varietas Ciherang, Cigeulis, Mekongga, Bandoyudo, widas, IR42, Inpari dan lainnya memberikan harapan peningkatan produktivitas padi sawah pada masing masing kabupaten di Jawa Barat.

Tabel 1. Rata-rata Hasil dan Potensi Hasil Beberapa Vrietas Unggul Padi

\begin{tabular}{lcc} 
Varietas & $\begin{array}{c}\text { Rata-rata Hasil } \\
\text { (Ton/ha) }\end{array}$ & $\begin{array}{c}\text { Potensi Hasil } \\
\text { (Ton/ha) }\end{array}$ \\
\hline Ciherang & 6,0 & 8,5 \\
Cigeulis & 5,0 & 8,0 \\
IR64 & 5,0 & 6,0 \\
Ciliwung & 4,8 & 6,5 \\
Mekongga & 6,0 & 8,4 \\
Bondoyudo & 6,0 & 8,4 \\
Widas & 5,0 & 7,0 \\
IR 42 & 5,0 & 7,0 \\
Inpari 1 1 $^{*}$ s/d & 7,3 & 10,0 \\
Inpari 44 Agritan & (2) \\
dll & & 9,53 \\
\hline
\end{tabular}

Sumber: - BB Padi, 2009, -*) Balai Penelitian dan Pengembangan Pertanian 2018

Pengamatan pada masing-masing kabupaten menunjukkan sepanjang periode 1997-2017 pertumbuhan produktivitas padi sawah rata-rata pada 16 kabupaten cukup ragam seperti ditunjukkan oleh Gambar 4. Pertumbuhan rata-rata tertinggi dijumpai di Kabupaten Tasikmalaya, yakni sebesar 1,41\% per tahun dan terendah di Kabupaten Bekasi sebesar $0,50 \%$ per tahun, dapat dilihat pada Gambar 4. Pertumbuhan produktivitas ratarata pada 16 kebupaten, tertinggi terjadi pada 
tahun 2008 sebesar 6,90\%, dan terendah pada tahun 2018 sebesar $-7,01 \%$.

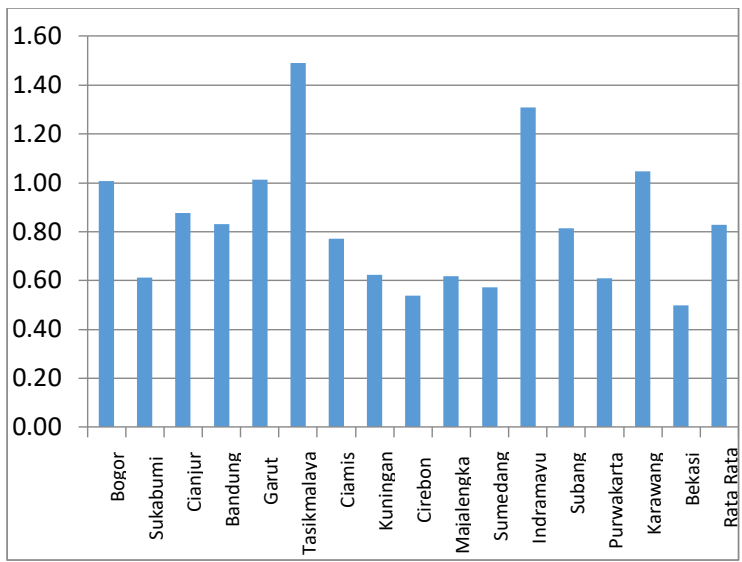

Sumber: Jawa Barat dalam Angka Tahun 1998-2018 (diolah) Gambar 4. Pertumbuhan Produktivitas Padi Sawah Rata-rata pada 16 Kabupaten di Jawa Barat Periode 1998-2017 (\%)

Peningkatan produktivitas padi sawah sangat penting dalam mengantisipasi menurunnya luas sawah. Penurunan luas sawah terjadi akibat meningkatnya kegiatan ekonomi dan jumlah penduduk yang membutuhkan lahan untuk industri dan perumahan, sementara lahan yang mudah dimanfaatkan adalah sawah yang mudah dijangkau. Penurunan luas sawah berpotensi dalam menurunkan produksi padi. Jika irigasi tersedia secara cukup, lahan sawah mampu untuk ditanam tiga sampai empat kali dalam setahun, atau Indeks Pertanaman (IP) 300\%$400 \%$. Kemampuan ini akan meningkatkan luas panen yang berlipat dalam setahun, sehingga mampu menghasilkan produksi yang berlipat yang berpotensi meningkatkan produktivitas lahan. Hasil penelitian Supriatna (2012) menunjukkan bahwa sepanjang kondisi ideal belum bisa terealisasi, maka IP Padi 300 lebih layak untuk dikembangkan daripada IP Padi 400. Program ini dapat dijadikan alternatif terobosan kebijakan mendorong peningkatan produksi beras nasional.

Sepanjang periode 1997-2016, nilai IP padi sawah di Jawa Barat diantara kabupaten dapat dilihat pada Gambar5.

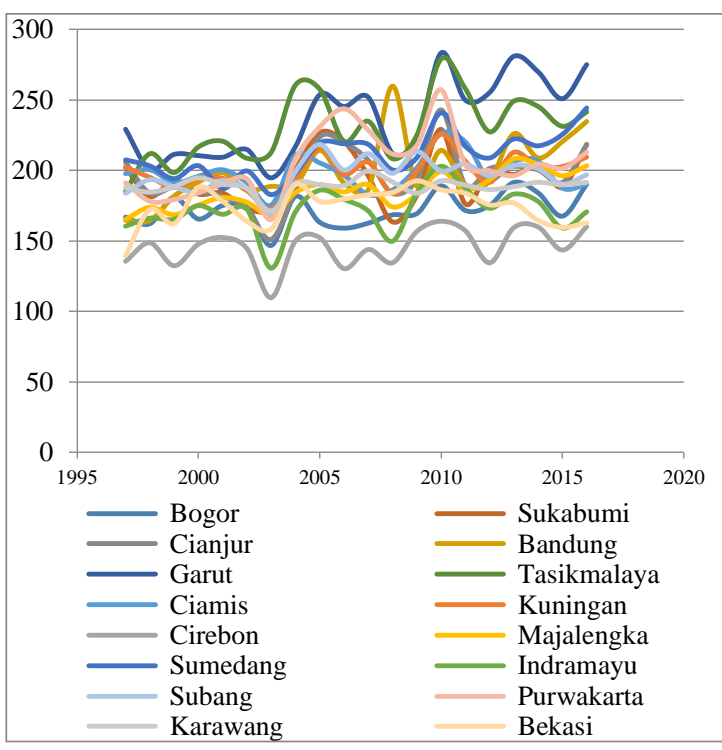

Sumber: Jawa Barat dalam Angka Tahun 1997-2017 (diolah)

Gambar 5. Perkembangan Nilai IP Padi Sawah Rata-rata pada 16 Kabupaten di Jawa Barat 1997-2016 (\%)

Pengamamatan pada 16 kabupaten menunjukkan bahwa nilai IP padi sawah ratarata pada periode tersebut sebesar 195,53\% per tahun, dengan IP terendah di Kabupaten Cirebon sebesar $146.71 \%$ dan tertinggi di Kabupaten Garut sebesar 239,31\%. Nilai terendah diantara 16 Kabupaten terjadi pada tahun 2003 sebesar 163,9\%, sedangkan nilai tertinggi terjadi pada tahun 2005 sebesar $207,85 \%$.

\section{Analisis Faktor-faktor yang Mempengaruhi Produktivitas Padi Sawah}

Model persamaan produktivitas padi sawah dalam persamaan regresi linier berganda dari fungsi produksi Cobb-Douglas padi sawah Jawa Barat dengan empat variabel bebas, yaitu: ketinggian tempat, curah hujan, luas irigasi, dan indeks pertanaman (IP). Variabel bebas tersebut merupakan gambaran kondisi wilayah dan iklim di Jawa Barat, asupan air irigasi sebagai salah satu variabel penting produksi pertanian, serta luas panen yang dinyatakan dalam IP sebagai input yang mewakili penghitungan produktivitas lahan. Model persamaan tersebut adalah: 
$\operatorname{Ln} Y=\beta 0+\beta 1 \operatorname{LnX} 1+\beta 2 \operatorname{LnX} 2+\beta 3 \operatorname{LnX} 3$

$$
+\beta 4 \operatorname{LnX} 4+\mathrm{e}
$$

$\mathrm{Y}$ : Produktivitas padi sawah $(\mathrm{Kw} / \mathrm{ha})$

$\mathrm{X}_{1}$ : Ketinggan Tempat $(\mathrm{m})$

$\mathrm{X}_{2}$ : Curah Hujan (mm)

$\mathrm{X}_{3}$ : Indeks Pertanaman/IP (\%)

$\mathrm{X}_{4}$ : Luas Irigasi (ha)

e : Kesalahan pengganggu (error term)

Hasil uji asumsi kalsik model persamaan OLS menunjukkan bahwa nilai VIP pada keempat variabel bebas kurang dari 10 dan nilai tollerance yang rendah sepserti ditunjukkan Tabel 2, memberi kesimpulan tidak terjadinya multikolinieritas diantara variabel bebas. Uji outokorelasi tidak dilakukan mengingat model perasamaan didasarkan pada data cross section pada tahun 2013. Uji heterosekedastisitas dilakukan dengan membuat Scatterplot (alur sebaran) antara residual dan nilai prediksi dari variabel terikat yang telah distandarisasi, hasilnya terlihat bahwa sebaran titik tidak membentuk suatu pola/alur tertentu, sehingga dapat disimpulkan tidak terjadi heteroskedastisitas atau terjadi homoskedastisitas. Uji normalitas didasarkan gambar Normal P-P Plot dengan hasil menunjukkan sebaran titik-titik dari gambar Normal P-P Plot mendekati garis lurus, sehingga dapat disimpulkan bahwa residual terdistribusi normal.

Hasil analisis regresi diperoleh persamaan: $\operatorname{Ln} Y=5,021+0,029 \operatorname{LnX} 1-0,129 \operatorname{LnX} 2-$ $0,062 \operatorname{LnX} 3+0,025 \operatorname{LnX} 4+\mu$. Dapat disimpulkan bahwa variabel ketinggian tempat berpengaruh nyata positif terhadap produktivitas padi sawah pada $\alpha 0,10$, dengan koefisien 0,029 , menunjukkan bahwa setiap kenaikan $1 \%$ ketinggian tempat mengakibatkan produktivitas padi sawah naik $0,029 \%$. Kenaikan produktivitas diduga akan terjadi sampai dengan ketinggian yang sesuai dengan varietas padi yang ditanam. Ketinggian tempat yang baik bagi varietas unggul berbeda beda. Sebagai contoh, menurut Kementerian Pertanian (2018) Varietas Ciherang, Mekongga, dan Inpari I baik ditanam pada ketinggian kurang dari 500 $\mathrm{m}$ diatas permukaan laut (dpl), sedangkan Inpari 2, Inpari 3, dan Inpari 4 baik ditanam pada dataran rendah sampai dengan ketinggian sekitar $600 \mathrm{dpl}$.

Tabel 2. Hasil Analisis Regresi Linier Berganda Produktivitas Padi Sawah pada 16 Kabupaten di Jawa Barat Tahun 2013

\begin{tabular}{lcccccc} 
Variabel & $\begin{array}{c}\text { Unstandardized } \\
\text { Coeffisients }\end{array}$ & $\begin{array}{c}\text { Standardized } \\
\text { Coeffisients }\end{array}$ & $T$ & Sig & Tolerance & VIP \\
\hline Konstanta & 5,021 & 5.233 & 0,000 & & & \\
Ketinggian tempat & 0,029 & 0,674 & 1,939 & 0,079 & 0,449 & 2.229 \\
Curah hujan & $-0,129$ & $-0,599$ & $-1,804$ & 0,099 & 0,492 & 2.033 \\
IP & $-0,062$ & $-0,121$ & $-0,375$ & 0,715 & 0,521 & 1.919 \\
Luas Irigasi & 0,025 & 0,200 & 0,627 & 0,544 & 0,534 & 1.874 \\
\hline
\end{tabular}

Sumber: hasil pengolahan data 
Variabel curah hujan berpengaruh nyata terhadap produktivitas padi sawah pada $\alpha 0,10$, dengan keofisien $-0,129$, menunjukkan bahwa setiap kenaikan $1 \%$ curah hujan mengakibatkan produktivitas padi sawah turun $0,129 \%$. Diduga bahwa tidak setiap tahun curah hujan meningkatkan produktivitas padi sawah, karena terdapat pola curah hujan yang menyebabkan peningkatan produktivitas padi sawah pada tahun tertentu. Penelitian ini menggunakan data cross section tahun 2013, sementara peningkatan produktivitas padi sawah sesuai hasil penelitian Faradiba (2020) di Jawa Barat menunjukkan bahwa peningkatan produktivitas padi sawah terjadi pada tahun 2006, 2009, 2012, 2015 sesuai dengan pola curah hujan yang terjadi setiap 3 tahun. Variabel IP dan luas irigasi tidak berpengaruh nyata terhadap produktivitas padi. Pada model persamaan ini, variabel yang tidak berpengaruh nyata, yaitu IP dan luas irigasi tetap dimasukkan dalam model persamaan produktivitas, karena produktivitas padi sawah tetap dipengaruhi oleh kedua variabel tersebut walaupun mungkin kecil pengaruhnya.

\section{KESIMPULAN}

Sepanjang periode 1997-2017, produktivitas padi sawah rata-rata di Jawa Barat yang diamati dari 16 kabupaten mengalami peningkatan dari $53,22 \mathrm{Kw} / \mathrm{ha}$ pada tahun 1997 menjadi 60,79 Kw/ha ton pada tahun 2017, dengan rata-rata produktivitas per tahun sebesar 55,92 Kw/ha. Pada periode tersebut produktivitas padi sawah rata-rata telah meningkat $7,57 \mathrm{Kw} / \mathrm{ha}$ atau peningkatan produktivitas rata-rata per tahun sebesar $0,83 \%$. Terjadi peningkatan produktivitas yang fluktuatif, dengan peningkatan negatif pada tahun 1998, 2001, 2004, 2010, 2012, 2014, 2015, dan 2017. Masih terdapat kesenjangan (gap) antara produktivitas padi sawah faktual dengan produktivitas potensial beberapa varietas unggul padi. Terjadi peningkatan luas panen padi sawah dari 1.697.649 ha pada tahun 1997 menjadi 1.765.895 ha pada tahun 2016, dengan peningkatan $0,60 \%$ per tahun. Nilai IP padi sawah di Jawa Barat sepanjang periode 1997-2016 bervariasi diantara kabupaten. Nilai IP padi sawah rata-rata periode tersebut sebesar $195,53 \%$ per tahun. Hasil analisis statistik faktor yang mempengaruhi produktivitas padi sawah di Jawa Barat menunjukkan variabel ketinggian tempat dan curah hujan berpengaruh nyata terhadap produktivitas padi sawah, sedangkan variabel IP dan luas irigasi tidak berpengaruh nyata.

\section{SARAN}

Perlu mengurangi kesenjangan produktivitas padi sawah antara keadaan faktual dangan petensial melalui pelaksanaan budidaya padi sawah yang baik (good agricultural practices), demonstrasi plot varietas unggul yang tahan terhadap serangan OPT serta disukai pasar, dan akses petani yang lebih mudah terhadap sarana produksi pertanian. Dengan memperhatikan perbedaan wilayah diantara kabupten di Jawa Barat, perlu perubahan sistem pertanian modern saat ini ke arah sistem pertanian berkelanjutan termasuk pertanian organik yang memiliki potensi yang besar dalam mempersempit kesenjangan produktivitas padi tersebut, serta menjaga kelestarian lingkungan. Perlu penelitian lebih lanjut dengan ukuran sampel yang lebih besar serta data runtut waktu (time series) untuk menguji pengaruh IP dan luas irigasi terhadp produktivitas padi sawah.

\section{DAFTAR PUSTAKA}

Ahmad, I.M.M, and K. Abbas. 2003. The Impact of Institutional Credit on Agricultural Production in Pakistan. MPRA. No. 3673.

Balai Penelitian Dan Pengembangan Pertanian. 2018. Deskripsi Vrietas Unggul Padi: Inbrida Padi Sawah Irigasi (Inpari), Hibrida Padi (Hipa), Inbrida Padi Gogo (Inpago), Inbrida Padi Rawa (Inpara). Kementerian Pertanian, Jakarta.

BB Padi. 2009. Deskripsi Varietas Padi. Balai Penelitian Dan Pengembangan Pertanian. Departemen Pertanian, Jakarta.

BPS. 1997-2015. Jawa Barat dalam Angka 1997-2015. Badan Pusat Statistik Provinsi Jawa Barat. 
BPS. 2016-2020. Provinsi Jawa Barat dalam Angka 2016-2020. Badan Pusat Statistik Provinsi Jawa Barat.

Ding, M., Chen, Q., Xiao, X., Xin, L., Zhang, G., \& Li, L. (2016). Variation in cropping intensity in northern China from 1982 to 2012 based on GIMMSNDVI data. Sustainability, 8(11), 1123.

Faradiba, 2020. Analisis Pola Curah Hujan Terhadap Produktifitas Tanaman Padi Sawah di Provinsi Jawa Barat. Jurnal EduMatSains, 4 (2) Januari 2020, 139152

Ishaq, M., A.T. Rumiati, dan E.O. Permatasari. 2017. Analisis Faktor-Faktor yang Mempengaruhi Produksi Padi di Provinsi Jawa Timur Menggunakan Regresi Semiparametrik Spline. Jurnal Sains Dan Seni ITS Vol. 6, No. 1, (2017) ISSN: 2337-3520 (2301-928X Print).

Lobell, D. B., Cassman, K. G., and Field, C. B. 2009. Crop yield gaps: Their importance, magnitudes and causes. Annual Review of Environment and Resources, pp.34, 1-26. https://www.annualreviews.org/doi/pdf/ 10.1146/annurev.environ.041008.09374 $\underline{0}$

Nurhati, I, S. Ramdhaniati1, dan N. Zuraida, 2008. Peranan dan Dominasi Varietas Unggul Baru dalam Peningkatan Produksi Padi di Jawa Barat. Buletin Plasma Nutfah Vol.14 No.1 Th.2008. :8-13

Pushpa and S.K. Srivastava. 2014. Yield gap analysis and the determinants of yield gap in major crops in eastern region of Uttar Pradesh. Economic Affairs 2014: 59(4): 653-662.

Raghav, G and K. Imai. 2008. Agricultural Growth, Employment, and Wage Rates in Developing Countries in Berlin Workshop Series. World Bank.

Rejekiningrum. P dan Kartiwa B. 2015. Upaya Meningkatkan Produksi Tanaman Jagung Menggunakan Teknik Irigasi Otomatis di Lahan Kering Kabupaten Lombok Barat, Nusa Tenggara Barat. Dalam: Prosiding Seminar Nasional Masyarakat Biodiversitas Indonesia. 1(8): 2027-2033.

Sihombing, D, Z. Arifin, and W. Handayati. 2019. Study of Rice Cropping Index Increasing On Dry Land in Malang-East Java. AIP Conference Proceedings 2120, $030030 \quad$ (2019); https://doi.org/10.1063/1.5115634. Published Online: 03 July 2019: 1-6.

Supriatna, A. 2012. Meningkatkan Indeks Pertanaman Padi Sawah Menuju IP Padi 400. Increasing Rice Cropping Index to Cropping Index of 400. Agrin Vol. 16, No. 1, April 2012: 1-18

Upadhyay, J. 2012. Climate Change and its Impact on Rice Productivity in Assam. http://dx.doi.org/10.2139/ssrn.2172183. 